\title{
Time of Displacement as a Predictor of Re-employment
}

I Arja Jolkkonen

Senior Researcher, University of Eastern Finland, Karelian Institute, Finland

I Pertti Koistinen'

Emeritus Professor, University of Tampere, Faculty of Social Sciences, Finland

\section{Arja Kurvinen}

Senior Researcher, University of Eastern Finland, Karelian Institute, Finland

\section{Liudmila Lipiäinen}

Researcher, University of Tampere, Work Research Centre (WRC), Finland

\section{Tapio Nummi}

University Lecturer, University of Tampere, Faculty of Natural Sciences, Finland

\section{Pekka Virtanen}

Docent, University of Tampere, Faculty of Social Sciences, Finland

\begin{abstract}
Previous studies addressing plant closures suggest that the reemployment of workers varies according to the economic cycle at the time of displacement. However, there are few studies on the selectivity of labor demand and reemployment in the long run. This study applied trajectory analyses in exploring the 7-year labor market attachment of workers displaced in plant closures in Finland during the recession in 1992, the boom in 1997, and slow economic growth in 2003. Results of the multinomial logistic regression analyses indicated that those displaced during the recession assumed the trajectory of strong employment significantly less commonly than those displaced under better economic conditions. Moreover, a significant interaction between age and year of displacement was found, whereas the gender, education-, and industryrelated risks turned out to be timeindependent. The study contributes to the sociological understanding of economic restructuring and how different times frame the individual's opportunities to gain re-employment.
\end{abstract}

\section{KEYWORDS}

displacement / economic restructuring / job loss / longitudinal data analysis / re-employment / trajectory analysis

\section{DOI}

To be announced

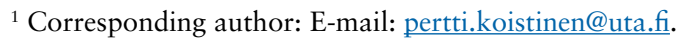




\section{Introduction}

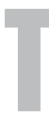

he recent history of industrial societies can be read through the continuous restructuring of economies. This restructuring affects the development of labor markets and the welfare of societies. In their seminal study on deindustrialization and unemployment in the OECD (The Organisation for Economic Co-operation and Development) countries over the last 30 years, Kollmeyer and Pichler (2013: 786) discuss whether deindustrialization has been an important but less recognized cause of the unemployment problems experienced by affluent countries. They found that despite the strengthening of research in this area, it is still unclear if there is a causal relation between deindustrialization and unemployment. One of the unanswered topics is how the interplay of economic shocks and structural labor market adjustment may affect employment, in particular the longer-term employment trajectories of redundant workers.

Previous research on re-employment after plant closures suggests that losing one's job is more damaging during a recession than during an economic boom (Farber, 2005, 2011; Frederiksen \& Westergard-Nielsen, 2007; Gartell et al., 2010; Hall et al., 1995; Jolkkonen et al., 2014; Kletzer, 1998). Furthermore, those who graduate in times of recession or are matched to the wrong industry in their first job are much more vulnerable to business cycle variation. In addition, institutional factors affect the employment opportunities of displaced workers, and policy differences between countries can lead to large differences in employment outcomes (Cutler et al., 2014; Houle \& Audenrode, 1995; Huttunen et al., 2011; Liu et al., 2016; Neffke et al., 2016).

Evidence from previous Finnish population-wide studies suggests that structural factors and economic cycles affect the re-employment and income development of displaced workers (Appelqvist, 2007; Verho, 2008). Those displaced during the recession of the early 1990s suffered from a substantial and persistent loss of earnings, and the effect of displacement was very heterogeneous and strongest at the lower end of the earnings scale (Korkeamäki \& Kyyrä, 2014). Studies applying trajectory analyses also demonstrate differentiation in the re-employment of displaced workers; the share of those who assume the trajectory of stable employment was quite high (Jolkkonen et al., 2014), although not as high as the corresponding share of employees who retained their positions following downsizings (Jolkkonen et al., 2017).

Despite the undisputed progress of the research, there are still many questions to be answered about the factors affecting the long-term employment of displaced workers. Outstanding questions concern how the state of the business cycle at the time of displacement is related to the employment trajectories in the long run, and if this relationship depends on individual factors. It is also important to separate employees experiencing plant closures from those experiencing downsizings, and to take into account variation in the stability of the employees' careers prior to displacement.

The present study extends across a period of 20 years and covers three different kinds of economic cycle in Finland. Representative registerbased data allow us to overcome the limitation of studies based on single plant closures and use longitudinal research settings and advanced statistics that encompass the structural and individual factors contributing to the labor market integration of displaced workers. The main objective is to reveal if the displaced workers' risk of falling onto different employment trajectories depends on the time of plant closure, taking into account their age, gender, level of education, and the industry of the previous workplace. In addition, we analyze

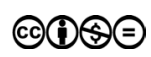


if the importance of unemployment as the reason for falling onto trajectories of poor employment depends on time.

The results clearly verify that the integrative capacity of the labor market is strong, as even in 1992, at a time of deep recession, half of the displaced employees were assigned to the group of continuously strong employment, and in 1997 and 2003, the corresponding proportions were about $80 \%$. The re-employment was also selective, providing fewer opportunities for older workers to fall onto a strong employment trajectory; moreover, there was an interaction between age and time of displacement, indicating that older workers displaced during the recession had particularly poor opportunities. By contrast, the associations of gender, education, and industry with re-employment were time-independent, indicating that permanent changes in the industry structures and associated labor force demands do not explain the result.

The strengths of this research lie in quality of the data and in novel methodological solutions. Moreover, we argue that Finland is an interesting case for studies of economic restructuring, because as an open and exportoriented economy, it has been sensitive to external shocks and labor market restructurings that have led to major layoffs, which in turn have necessitated employment policy reforms. Furthermore, Finland provides an environment conducive to intensive social scientific research into the reemployment options of displaced workers.

\section{Literature review and theoretical framework}

Already back in the 1970s, Peter Barth presented an interesting perspective on economic cycles and labor market adjustment. According to his theoretical formulations and time series analysis of displacement rates, he argued that different firms may respond differently to identical changes in their own product market when general labor market conditions differ. The employment rate of displaced workers is higher when the displacement takes place in times of economic expansion than in times of recession, yet the demand for labor varies considerably by firm and industry type. The selective demand for labor may lead to a situation where the labor demand is not targeted at those who lost their jobs, because their skills do not match the needs of the labor market (Barth, 1971: 452). This is in accordance with Lilien's (1982) 'sectoral shift' thesis, according to which fluctuations in demand across sectors account for a substantial fraction of the variation in unemployment and the declining sectors of the economy typically increase unemployment rates because the reallocation of workers across disparate industries occurs slowly. The times of recession are harder for job-seekers but easier for recruiting firms because there are more job applicants (Chiarini \& Piselli, 2001; Kollmeyer \& Pichler, 2013: 786; Neffke et al., 2016).

The human capital theory has been commonly applied to studies of job displacement. From a human capital perspective, the distribution of employment, earnings, and income after displacement can be tied directly to differences in levels of education and training (Becker, 1975; Koeber \& Wright, 2006; Ormiston, 2014). Human capital is often divided into two categories: general, which is widely applicable to many employers, and specific, which can be unique to a certain employer or job (Kletzer, 1998). General human capital can be measured by the level of education and it is transferable across employers. In addition to education, there is evidence that gender, age, and the industry 
of the previous employer are important factors for re-employment after job loss. However, it has not been studied how business cycles and individual factors together influence the development of employment trajectories in the long term.

Gartell et al. (2010) used Swedish data from 1986 to 2002 to study cyclical patterns of job and worker flows: they found that job reallocation is countercyclical. However, when estimating correlations for groups according to education, job reallocation was countercyclical for the lowest educated and acyclical for the higher educated groups. Contrary to job flows, worker flows were acyclical with a strong procyclical pattern of hiring rates, and there was an acyclical pattern in separation rates (Gartell et al., 2010). Furthermore, institutional factors and the structure and function of the local labor market affect mass layoffs and the re-employment opportunities of displaced workers (Farber, 2011, 2005; Frederiksen \& WestergaardNielsen, 2007; Jolkkonen \& Kurvinen, 2009).

Existing studies on job separation and reallocation provide evidence that many of those who are laid off by their longterm employer suffer income losses even if they are re-employed. Korkeamäki and Kyyrä (2014) discovered that displaced workers suffer from a substantial and persistent loss of earnings, women are subject to larger losses, and the effect of displacement is very heterogeneous and strongest at the lower end of the earnings scale. Displacement not only causes large losses in expected earnings but also raises the instability of future earnings. Verho (2008) compared the earnings of men who lost their jobs due to a plant closure during the Finnish recession of the early 1990s with the earnings of those who remained in employment. After a 7-year followup, he found a significant earnings penalty for those who were unemployed as well as for those whose employment recovered steadily after the recession. The lower incomes were explained by the reduction of employment months and a lower wage level.

When examining the short- and long-term effects of displacement on workers' employment and earnings in Norway, Huttunen et al. (2011) found that, on average, displacement increases the probability of leaving the labor force by $30 \%$. The dropout rate from the labor force among the older workers was particularly high in the first years following displacement. The long-term effect was the greatest for middleaged workers (aged 45-57), who were the most likely to remain outside the labor force 7 years after displacement.

Farber (2011) used the Displaced Workers Survey (DWS) to investigate the incidence and consequences of job loss in the USA from 1981 to 2009. According to his results, it was clear that those who lost their jobs during the 2007-2009 period recorded a higher rate of job loss and greater difficulties in reemployment when compared to other periods of economic development. Nearly one in six workers reported having lost a job in the 2007-2009 period, and these individuals also reported very low rates of reemployment, difficulty in finding full-time employment, and substantial earnings losses. Farber discovered that there were strong differences in postdisplacement labor force status by age. Prime-aged (25-54 years of age) workers who lost their job had the strongest attachment to the labor force, while older workers (55-64 years of age) were substantially more likely to be out of the labor force. Nevertheless, all age groups suffered during the 2007-2009 recession (Farber, 2011: 10-13).

Ormiston (2014) extended the scope of questions and asked why displaced workers lose so much value in the labor market. Using representative occupational data from US Department of Labor and the DWS surveys, he found that displaced workers have greater difficulties in times of recession than economic growth, but the results suggest that a link between occupation-specific human capital transferability and postdisplacement 
earnings upon re-employment is independent of the state of the macro-economy (Ormiston, 2014: 375).

Stevens (1997) examined the long-term wage and earnings losses of displaced workers using the Panel Study of Income Dynamics. She discovered that much of the persistent effect of job loss can be explained by additional job losses in the years following an initial displacement, and that those losing jobs due to downsizing are somewhat more likely to experience additional displacements compared to those losing their job due to plant closure.

Previous research on re-employment after mass layoffs has shown that the risk of ending up unemployed is highest among young workers and lowest among the oldest workers. However, it is easier for young people to become re-employed, whereas older workers often become long-term unemployed or move outside the labor market (Eliason \& Storrie, 2009; Hall et al., 1995; Jolkkonen \& Kurvinen 2009; Korkeamäki \& Kyyrä, 2014; Verho, 2008). Older workers lose more than their younger colleagues in layoffs because their re-employment options tend to be limited and they tend to experience considerable wage losses. On the other hand, older workers and those with long work histories are less likely to be displaced because layoffs are often based on the rule of 'last in, first out' (Boockmann \& Steffes, 2007; Kuhn, 2002). It has also been shown that highly educated and white-collar workers have better reemployment opportunities than the unskilled and less educated, despite the fact that displacement among educated workers is increasing (Farber, 2011; Jolkkonen et al., 2012; Kletzer, 1998; Kuhn, 2002; Ormiston, 2014). The results of Nedelkoska et al. (2015) from Germany show that a qualification mismatch is particularly common among well-qualified employees, at least during the first years of re-employment.

The effects of gender and length of work history are more complex than those of age and education. In many countries, men are more likely to be displaced than women, but in regard to career stability and earnings, women lose even more than men (Kuhn, 2002). More frequently than men, women move outside the labor force into domestic work, end up seeking further education, or change occupation if they cannot find a new job in the field (Farber, 2011; Jolkkonen \& Kurvinen 2009). Evidence from Denmark shows that there are no gender differences in job separation probabilities for employees in similar workplaces, but there is a clear difference in job stability because, more often than men, women work in jobs that are more insecure, and the transition models of men and women are different. Women also more commonly move from employment to unemployment or out of the labor force, and they are less likely to make job-to-job transitions (Frederiksen, 2008: 915).

Studies prove that employers are very selective in terms of age, education, gender, and social characteristics when recruiting new labor, but, in the case of their former workers, the criteria for recruitment are more flexible (Klingvall, 1998). It seems that displaced workers who lose their jobs in plant closures have a better reputation with employers than those who lose their jobs in workforce reductions because, first, employers believe that the reason for dismissal was in general economic, and second, employers assume that awkward individual characteristics and low productivity were not the cause of dismissal (Jolkkonen et al., 2012). These findings are important when set in the wider context of the restructuring and reallocation of labor.

Taken together, this review of the existing literature clearly demonstrates that reemployment depends on structural, institutional, and individual factors. The time of 
displacement and the extent and type of restructuring explains the differentiation of the re-employment opportunities of displaced workers. In times of recession and economic growth, the criteria of recruitment and the selectivity of inflows and outflows from unemployment vary. There are, however, shortcomings in the research evidence. For instance, many studies pool employees in their analyses irrespective of the type of displacement (i.e., plant closure or downsizing or single layoffs), thus discarding an important predictor of future employment. This is the reason why we concentrate on plant closures in this study. Another important but seldom controlledfor predictor is the stability of the worker's contract in the service of the plant that has closed; in the present study, relatively stable employment is a prerequisite for inclusion in the sample. Moreover, we construct an employmentrelated indicator of labor market attachment and use statistical methods that have not been applied before in this domain.

Based on economic theories and previous studies on the reemployment of displaced workers, the present study aims to provide support for the hypothesis that labor market integration is weaker when the displacement occurs during an economic recession than during a period of recovery and growth. Moreover, leaning on the sectoral shift hypothesis, we assume that this weakness of integration is due to permanent changes in industry structures and the associated selectivity of labor force demand. We expect to find that the less educated and those working in primary and secondary production are more vulnerable to weak integration when displaced during a recession.

\section{Socioeconomic context}

To discover the effect of structural factors and cyclical and temporal time, we pooled the data of workers displaced due to plant closures during three different types of business cycle, corresponding to the years 1992, 1997, and 2003. The cyclical development of the economy is usually illustrated by the indicators of gross domestic production (GDP), employment rate, and unemployment rate (Farber, 2011; Frederiksen \& Westergaard Nielsen, 2007; Korkeamäki \& Kyyrä, 2014). These indicators show that 1992, 1997, and 2003 each represent a different macroeconomic cycle (see Fig. 1).

In 1992, Finland was in an exceptionally deep recession with high unemployment. Between 1991 and 1993, the unemployment rate increased from $8 \%$ to almost $20 \%$. In 1997, the unemployment rate was still about $16 \%$, but it decreased to $11 \%$ in 2003 . The year 1997 was a time of economic boom after the earlier recession. The speed of Finland's economic growth slowed after 2001, although the demand for labor and the employment rate were still increasing and the number of plants and their employees were at a higher level in 2003 than during 1992 and 1997. However, structural changes, such as the rapid development of technology and changes in occupational structure, were characteristic of the beginning of the 2000s (Asplund et al., 2012; Statistical Yearbooks of Finland, 1990-2013). Although 2003 was characterized by slow economic growth, there was demand for labor, because in spite of the closure of businesses, new firms were also created.

Between 1992 and 2010, there were several changes in the pension and social security schemes that postponed an exit from the labor force (e.g., a pension reform in 2005 and changes in unemployment benefits). The unemployment exit route was based on unemployment compensation. It consisted of unemployment benefit schemes 
Figure I: Employment, unemployment, and economic development in Finland, 1990-201 I.

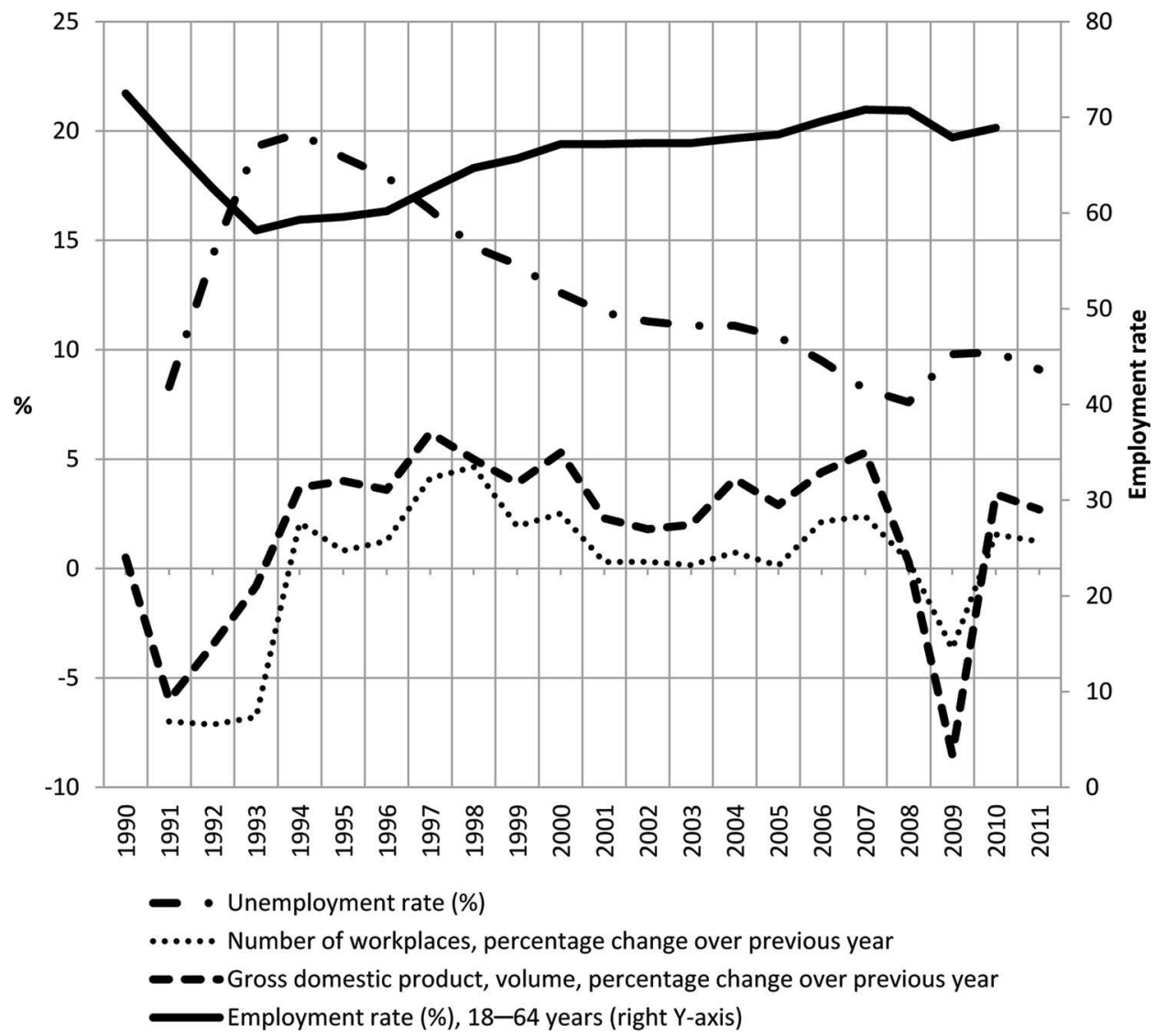

Sources: Statistics Finland, Annual national accounts; Statistics Finland, Statistical Yearbook of Finland, 1990-2013; Statistics Finland, StatFin database; Ministry of Employment and the Economy, Annual Employment Service Statistics 1991-2013; Authors' calculations.

and an unemployment pension. A so-called 'unemployment pension tube' was available between 1986 and 2005, which granted an automatic extension of the earnings-related unemployment allowance for the older unemployed who were approaching retirement (Järnefelt, 2010; Kyyrä, 2015).

\section{Data and methods}

\section{Data}

We used Finnish Longitudinal Employer-Employee Data (FLEED,${ }^{1}$ Statistics Finland), which comprises a random sample of one-third of the whole population aged 15-70 
living in Finland between 1988 and 2011. Drawing on several administrative registers, the FLEED database includes information on the subjects' individual characteristics, income, and employment history. There is also a variable indicating their labor market status at the end of each year and, for the employed, an identity code for the plant or company where the workplace is located. Using the code, it is possible to identify the employees of a given plant from the sample. As the data offer codes for all plants that exist in Finland at the end of each year, it is possible to determine which plants have exited the markets during the previous year. As we were interested in plant closures in 1992, 1997, and 2003, we defined a plant as closed if it existed for a 3year period preceding one of these years but did not exist during the next 3year period. Moreover, the plant had to be represented in the FLEED database by at least one employee at the end of 1991, 1996, or 2002, as applicable. Plants of fewer than 10 employees were not included. Changes in ownership, mergers, and outsourcings where more than $70 \%$ of the personnel moved into the service of a new employer were not considered closures.

The study sample consists of individuals who had been employed at the plant for 3 or more years before the closure and during these years had not been unemployed or participated in labor market policy measures (cf. Korkeamäki \& Kyyrä, 2008: 7). Thus, the study concerns individuals with a strong labor market status prior to the displacement. Those who moved abroad or died during the closure year were excluded, as were those who in the preceding year were younger than 20 or older than 60 .

In addition to gender, age, vocational education (classified as none, secondarylevel, lower tertiarylevel, and highertertiary level), and industry (primary production, secondary production, services), we extracted from the FLEED database two variables indicating the individuals' labor market attachment during the 7year period following the displacement. The number of months in employment during each calendar year was used as the response variable in the trajectory analyses, and unemployment during the

Table I Gender, education, age, and industry of the displaced employees according to the year of plant closure

\begin{tabular}{lccc}
\hline & \multicolumn{3}{c}{ Year of displacement } \\
\cline { 2 - 4 } & 1992 & 1997 & 2003 \\
\hline Number of plants & $(\mathrm{N}=985)$ & $(\mathrm{N}=1242)$ & $(\mathrm{N}=3339)$ \\
Gender & 433 & 149 & 532 \\
Male & & & $1468(44 \%)$ \\
Female & $650(66 \%)$ & $572(46 \%)$ & $187 \mid(56 \%)$ \\
Vocational education & $335(34 \%)$ & $670(54 \%)$ & $782(23 \%)$ \\
None & $425(43 \%)$ & $426(34 \%)$ & $1214(36 \%)$ \\
Secondarylevel & $355(36 \%)$ & $513(41 \%)$ & $946(28 \%)$ \\
Lower tertiarylevel & $189(19 \%)$ & $27 \mid(22 \%)$ & $397(12 \%)$ \\
Higher tertiarylevel & $16(2 \%)$ & $32(3 \%)$ & $44.5(9.3)$ \\
Mean age (SD) & $40.6(9.8)$ & $43.6(8.4)$ & \\
\hline
\end{tabular}

SD: standard deviation 
year was monitored with a dichotomous variable indicating if there had been a spell of more than 3 months without work.

A total of 5566 individuals were eligible for the study sample (see Table 1). The subsample from 1992 was maledominated, with a mean age 3 years lower compared to the subsamples from 1997 and 2003. The proportion of those with at least lower tertiarylevel education grew from $21 \%$ in 1992 to $40 \%$ in 2003 . Few employees worked in the primary industry; the division between the secondary industry and services was about half and half in 1992, while in 1997 and 2003, about threefourths of employees worked in the services sector.

\section{Statistics}

Trajectory analysis, or latent class growth analysis (Nagin, 1999; 2005), was applied in determining the various reemployment patterns of the displaced employees. This method requires that the individuals be followed up over time so there are measurements from different time points. The purpose of this is to find clusters of individuals that, with respect to the measured property, assume the same kind of development. For example, there might be one group with a pattern of changing values and another group with unchanged values. Starting from the assumption that there are such different developmental patterns 'hidden' in the data, trajectory analysis is able to identify a proper set of patterns and their shapes so that each individual is assigned to the most appropriate pattern. An important assumption is that the measurements within a trajectory group are taken to be independent. The statistical procedure involves searching for the number of trajectory groups where the probability of each individual being classified in a particular trajectory group is as high as possible, while it is hoped that the probability of that same individual belonging to any other group is as low as possible. This solution is obtained by trying out different models, comparing different statistical criteria, and visually interpreting the emerging trajectories (Jones et al., 2001; Jung \& Wickrama, 2008; Nagin, 2005). Finally, the trajectories should fulfill the common sense criterion, that is, their interpretation should fit the substantial nature of the property of interest, which in our study was employment, measured as months in a calendar year over 7 successive years.

Trajectory analysis estimates the model parameters on the basis of the method of maximum likelihood. In this study, the estimates were calculated iteratively using the Expectation and Maximization (EM) algorithm (Dempster et al., 1977). Bayesian information criteria (BIC) were considered in choosing the best solution-that is, the optimal number of trajectory groups.

After producing the trajectory groups, we applied multinomial logistic regression analyses to compare the closure years with respect to the distribution of individuals into different groups. The analyses were made first with crude figures, then the individual factors (gender, age, education, industry) were introduced to the model separately, and the final model includes all factors. Since the trajectory groups are based on probabilities-they are not fixed constructs-the regression analyses were weighted with the posterior probability of belonging to the chosen (i.e., the most likely) trajectory group. 


\section{Results}

\section{Employment trajectories}

For the response variable in our trajectory analysis, we assumed a Poisson distribution, which is often applied for counts data. To model the development, we applied a seconddegree polynomial model since according to the BIC values (not shown), the firstdegree model (linear curve) did not sufficiently model the development within the trajectory groups. Solutions from one to eight trajectory groups were tried, and each solution was confirmed by 30 repetitions. The program was not able to produce more than five trajectory group solutions due to convergence problems. BIC values decreased regularly from $306,806.9$ for one group to $215,807.0$ for five groups, indicating that the best solution consisted of five trajectory groups (Fig. 2).

The largest group, representing about twothirds of the sample, had been employed close to 12 months for all years of the follow-up period; the employment of this group was labeled 'strong'. The group $(6 \%)$ assuming the trajectory that drops down in the beginning but after a few years turns upwards was labeled 'recovering'. The remaining three groups were of about equal size: their trajectories ended at the zero-level, indicating an exit from employment either 'immediately', with a 'short delay' (1-2 years), or with a 'long delay' (3-4 years).

\section{Year of displacement as a determinant of employment trajectory}

Cross-tabulation of the trajectory groups by the year of plant closure (Table 2) shows that of those displaced in 1992, less than half ended up on the trajectory of strong employment, while in 1997 and 2003, the corresponding figures were $78 \%$ and $80 \%$, respectively. The low figure for the 1992 subsample is explained by the high figures for immediate exit $(21 \%)$ and recovering $(24 \%)$ employment, while long-delay exit was relatively rare in 1992 .

Multinomial logistic regression analyses (Table 3) confirmed that, with reference to being assigned to the trajectory of strong employment and the year 1997, in 1992, there was a significantly increased risk for immediate exit [a relative risk ratio (RRR) of 14.7 and a confidence interval (CI) of 9.9-21.8 that does not include 1, meaning the difference is statistically significant]; on the other hand, the chances of entering the trajectory of recovering employment were also much better (RRR 12.63, CI 8.58-18.6) in 1992 than in 1997.

In light of the absolute figures, the differences between 1997 and 2003 were quite small. The regression analyses showed that in 2003, immediate exit and recovering employment were significantly rarer.

The education, gender, and industryrelated risks for different trajectories did not depend on the year of plant closure, as indicated by the almost unchanged RRRs after introducing these variables into the regression models. Adjustments for age, on the contrary, had considerable impacts: RRRs for the trajectory of short-delay exit increased in 1992 and decreased in 2003, and similar and even more pronounced changes were seen in the risks for the immediate exit trajectory. This observation gives us a reason to explicate the importance of age in more detail.

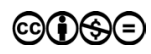


Figure 2: Illustration of the five 7-year employment trajectories of employees ( $N=5566)$ displaced in plant closures. The curves of yearly means are plotted from the original data using the predicted trajectory groups.

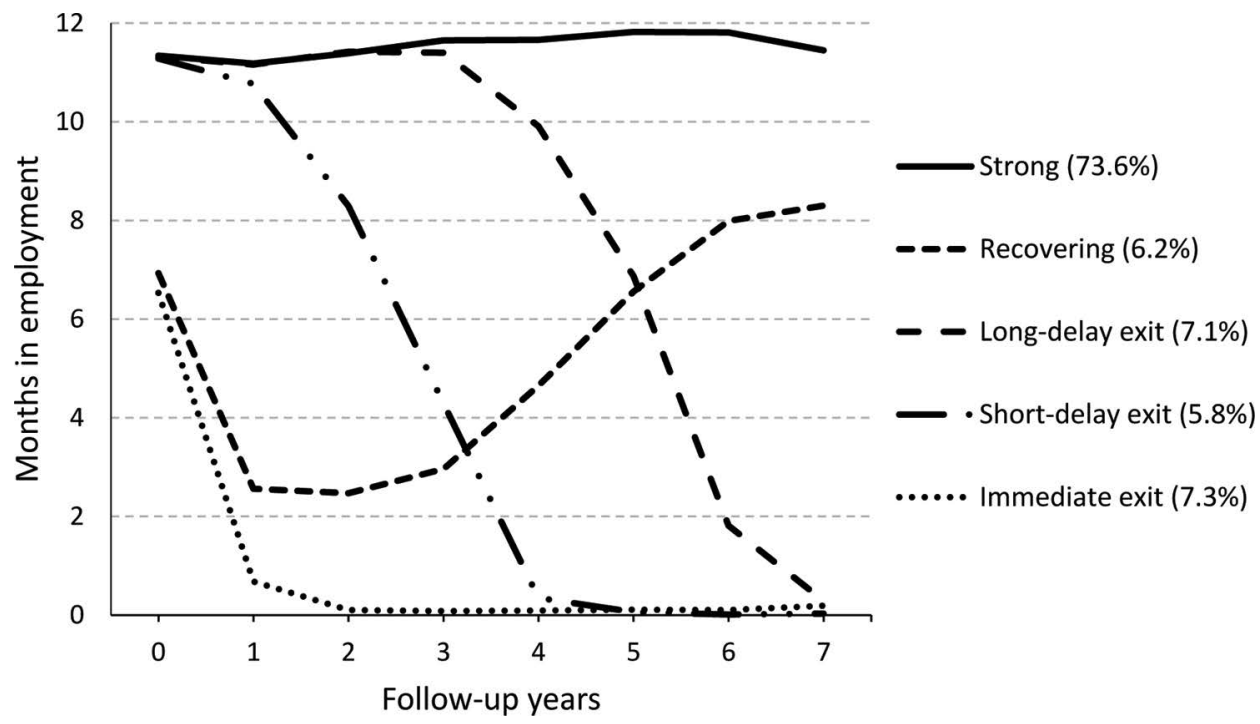

Table 2 Seven-year employment trajectories of the displaced employees according to the year of plant closure

\begin{tabular}{|c|c|c|c|c|c|c|}
\hline \multirow{3}{*}{$\begin{array}{l}\text { Employment } \\
\text { trajectory }\end{array}$} & \multicolumn{6}{|c|}{ Year of plant closure } \\
\hline & \multicolumn{2}{|c|}{1992} & \multicolumn{2}{|c|}{1997} & \multicolumn{2}{|c|}{2003} \\
\hline & $\mathrm{N}$ & $\%$ & $\mathrm{~N}$ & $\%$ & $\mathrm{~N}$ & $\%$ \\
\hline Strong & 460 & 47 & 967 & 78 & 2668 & 80 \\
\hline Long-delay exit & 30 & 3 & 93 & 8 & 274 & 8 \\
\hline Short-delay exit & 55 & 6 & 72 & 6 & 195 & 6 \\
\hline Immediate exit & 203 & 21 & 69 & 6 & 137 & 4 \\
\hline Recovering & 237 & 24 & 41 & 3 & 65 & 2 \\
\hline Total & 985 & 100 & 1242 & 100 & 3339 & 100 \\
\hline
\end{tabular}

\section{Age as a critical factor}

First, we classified the sample into young (the lowest age quartile, range 20-37 years), middleaged (the second and third quartiles combined, range 38-51 years), and older (the highest quartile, range 52-60 years), and plotted their trajectories by year of displacement (Fig. 3). Hardly any young employees fell onto the exit trajectories in any subsample, and these trajectories were also quite rare among the middle-aged, whereas the majority of the older employees assumed some kind of exit trajectory. Moreover, 


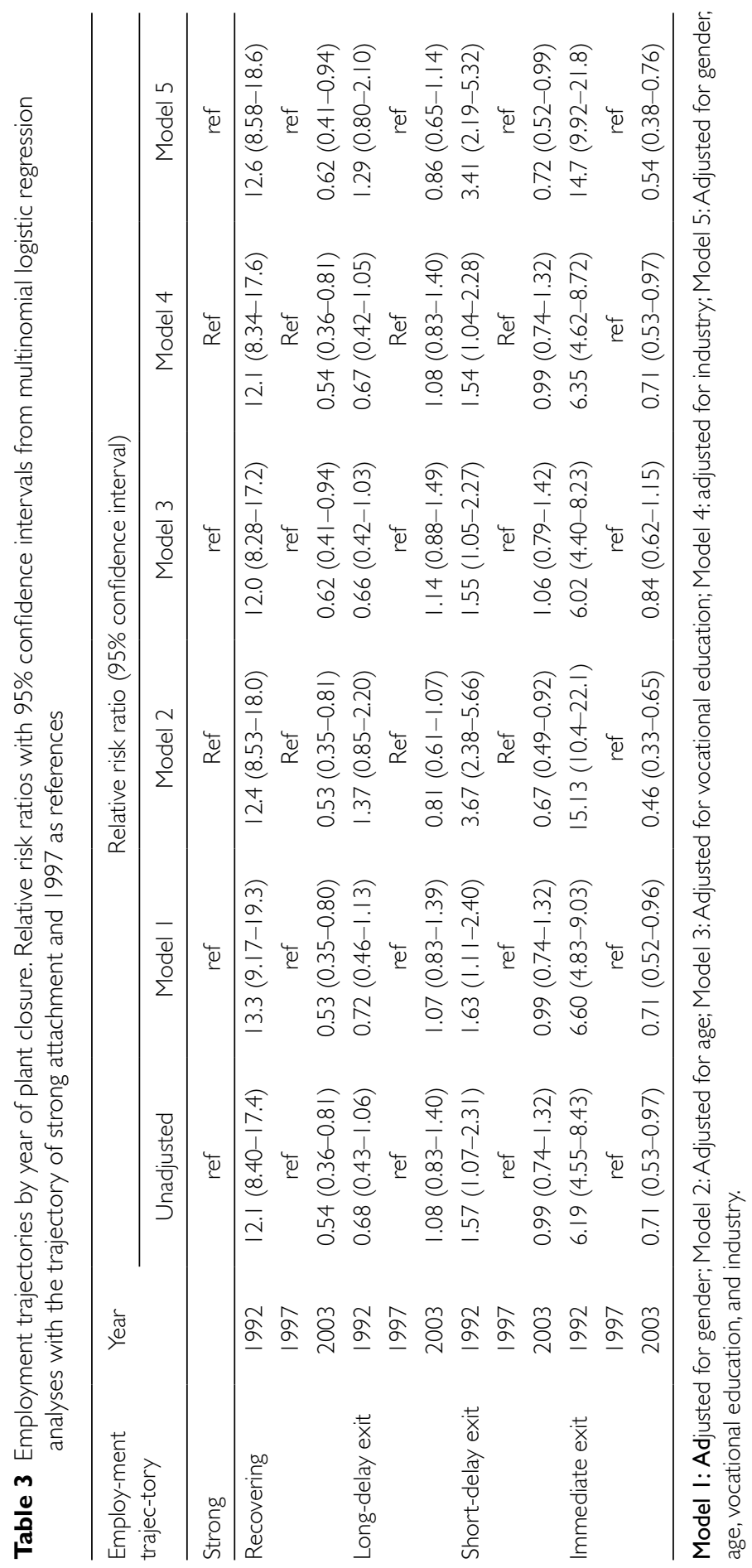


Figure 3: Seven-year employment trajectories of young (20-37 years), middleaged (38-5I years), and older (52-60 years) employees displaced in plant closures in 1992, 1997, and 2003.

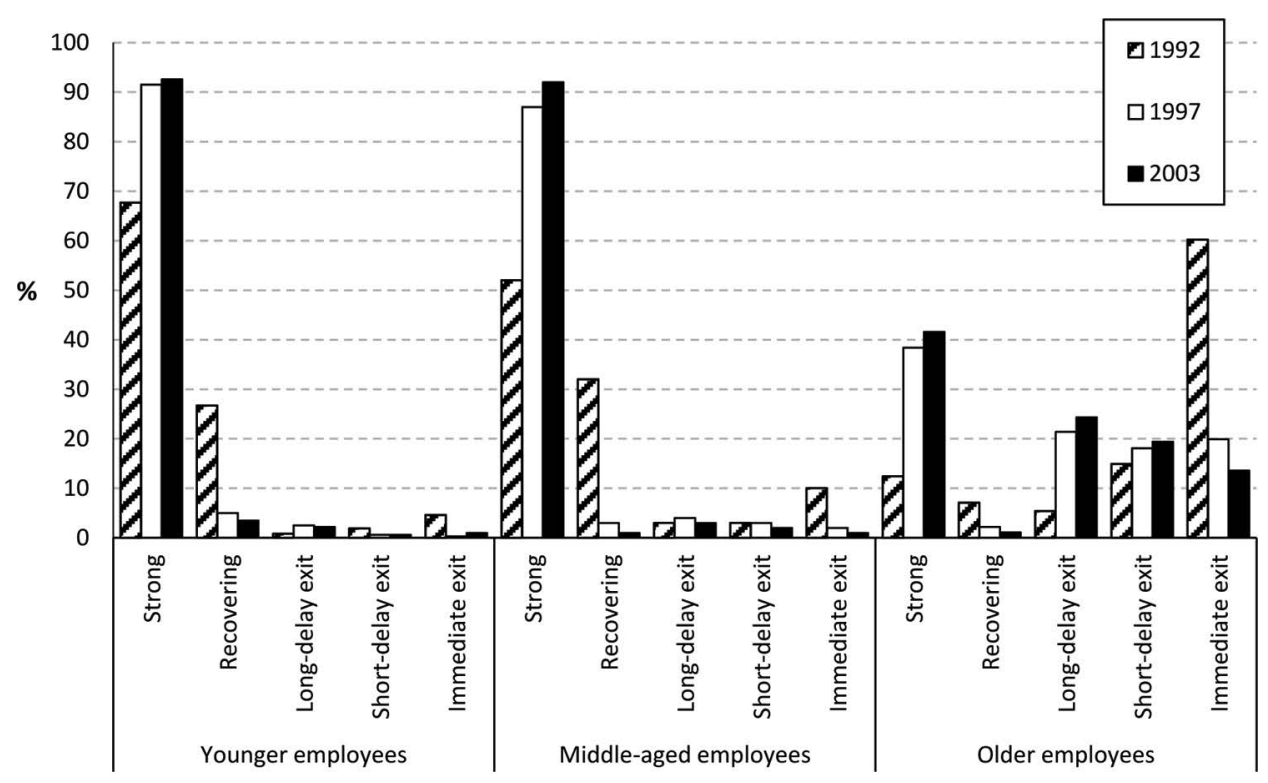

the agestratified figures clarify the closing yearrelated differences: most strikingly, threefourths of the older employees in 1992 were assigned to the trajectory of immediate exit, compared to $22 \%$ in 1997 and $12 \%$ in 2003. In 1992, the trajectory of strong employment was also very uncommon among the older employees.

Second, we fitted a generalized additive model (GAM) in order to further investigate the nonlinear effect of age (Wood, 2006). GAM is an extension of the Generalized Linear Model (GLM) that can be used when modeling the response variables from the exponential family of distributions with linear predictor variables. In our model, age was taken as a smooth term and the other model terms were considered as ordinary parametric terms. The response variable in each of these analyses was the probability of belonging to the trajectory group under consideration vs. all the other groups. The interaction term of year of displacement and age was tested using the likelihood ratio test. The interaction turned out to be statistically significant $(p<0.001)$ only in the case of the strong employment trajectory group (Fig. 4). The figures for the analyses of recovering employment and immediate exit from employment are given in Appendix A (Figs. A1 and A2, respectively).

As can be seen in Fig. 4, in all years, the effect of age on the probability of belonging to the trajectory of strong employment was significantly positive (the curve and CI above zero) in the middleaged workers and significantly negative (on the logit scale) in the older workers. In the young workers, the effect of age was positive in 1992, no effect was seen in 1997, and in 2003 the effect of age tended to be negative. Moreover, the figures demonstrate that the age when the curve crosses the zero-level-that is, the effect of age switches from positive to negative-increased from 48 years in 1992 to 52 years in 2003.

The effect of age on the probability of young workers (age $\leq 35)$ falling onto the trajectory group of recovering employment was not significantly positive in 1992, while 
Figure 4: The effect of age, controlling for gender and level of education, on the probability of falling onto the trajectory of strong employment for workers displaced in 1992, 1997, and 2003.
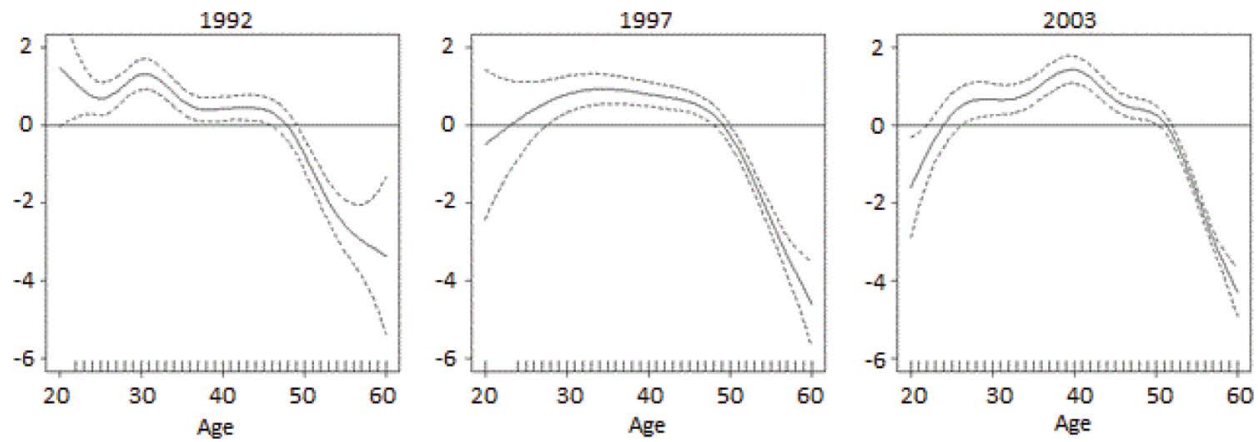

Note: Logit scale on the $y$-axis. The dashed lines show the $95 \% \mathrm{Cl}$.

in 1997 and 2003 being young seemed to have a positive effect on the probability of belonging to this group (Appendix, Fig. A1). For older workers ( $>50$ years), the effect of age was negative only in 1992.

The effect of age on the probability of belonging to the immediate exit trajectory group compared to other groups switched from negative to positive at around 45 years of age (Appendix, Fig. A2). After the recession year (1992), this turning point seems to come somewhat later.

The importance of age suggests that many individuals assigned to the trajectories ending in exit were excluded from the labor force through retirement. However, in the present study, our focus is not on various pensions or other institutions enabling more or less permanent positions outside the work force. Instead, we examined unemployment as the reason for weak labor market attachment (Table 4). The figures show that unemployment contributed to a much greater extent to all types of exit trajectories in 1992 than in 1997 and 2003.

Table 4 Unemployment of more than 3 months among the employees assigned to different exit trajectory groups during the first, fourth, and seventh year subsequent to plant closures in 1992, 1997, and 2003

\begin{tabular}{lcccccccccc}
\hline \multirow{2}{*}{$\begin{array}{l}\text { Employment } \\
\text { trajectory }\end{array}$} & \multicolumn{9}{c}{ 1992 } & \multicolumn{9}{c}{1997} & \multicolumn{2}{c}{2003} \\
\cline { 2 - 11 } & \multicolumn{3}{c}{ Follow-up years } & \multicolumn{3}{c}{ Follow-up years } & \multicolumn{3}{c}{ Follow-up years } \\
\cline { 2 - 10 } & 1993 & 1996 & 1999 & 1998 & 2001 & 2004 & 2004 & 2007 & 2010 \\
\cline { 2 - 10 } & $\%$ & $\%$ & $\%$ & $\%$ & $\%$ & $\%$ & $\%$ & $\%$ & $\%$ \\
\hline Long-delay exit & 43 & 20 & 33 & - & 8 & 24 & 3 & 7 & 15 \\
Short-delay exit & 33 & 73 & 36 & - & 26 & 11 & 3 & 20 & 3 \\
Immediate exit & 84 & 49 & 25 & 45 & 20 & 7 & 30 & 9 & - \\
\hline
\end{tabular}

Note: Observations that contain fewer than four individuals are not reported. 


\section{Discussion}

The present analysis of the employment trajectories of a sample of employees displaced at plant closures under three different macroeconomic conditions revealed five trajectory groups which, with respect to reemployment, were labeled 'strong', 'recovering', 'long-delay exit', 'short-delay exit', and 'immediate exit'. About threefourths of the sample was assigned to the strong employment group, while the share of the other groups varied between $5 \%$ and $7 \%$. As hypothesized, the distribution of the employees to different trajectory groups turned out to be related to the time when the closure occurred. Among those displaced during the recession of 1992, weak labor market attachment due to unemployment was more common than among those displaced in 1997 and 2003, despite the rapid economic growth and declining unemployment of the mid to late 1990s.

On the other hand, the results suggest that the selectivity of labor demand with respect to education and industry was similar at all the three time points. The sectoral shift and regional change play an important role in the restructuring of economy. However, a more detailed analysis of regional and industry factors remains to be tackled methodologically and theoretically in the forthcoming studies. Thus, we did not receive support for our secondary hypothesis, namely that during the economic crisis (1992), the 'sectoral shift' would be more profound. This finding, of course, does not question the fact that in 1992 there was a major change in Finland's industrial structure resulting in a substantial portion of the workforce becoming permanently redundant. Our conclusion is that among a particular group of employees, or those displaced in plant closures, the selectivity of reemployment with respect to the quality and quantity of the human resources is largely independent of the macroeconomic conditions.

Although an unexpected finding rather than a hypothesisrelated result, the strong age*year interaction on labor market attachment gave us reason to devote some effort and space to post-hoc analyses that aimed to clarify the role of age. The agestratified analyses showed that, overall, young employees hardly ever fell onto exiting trajectories, and these trajectories were also quite rare in the middleaged, whereas more than half of employees in the highest age quartile had dropped to zero employment by the end of the follow-up. Moreover, the year-related difference was most prominent in the oldest age quartile. The analysis with a GAM, where age is treated as a smooth term, specifies the nonlinear effect of age. In this study, our results are consistent with the existing studies that underline the selective effect of the individual's age on successful reemployment (Farber, 2011; Frederiksen, 2008; Huttunen et al., 2011). However, demonstration of the nonlinear effect of age and-in the case of the strong employment trajectory-the significant year-related differences bring new light to the discourse. On the other hand, the finding raises questions about the agespecific effects of institutions and the recruitment practices of employers that remain to be answered in further studies. The need of such studies is emphasized by the relatively minor role of unemployment, in particular among those displaced in 1997 and 2002.

Regarding the study sample, we have arrived at three important solutions. First, concentrating on plant closures alone yielded a sample that was-as far as possiblerandom (i.e., not selective) with respect to employability, as is the case in staff downsizings, not to mention lay-offs of individual employees. Second, in order to be included in the sample, individuals had to have an employment history of at least 3 years at the 
plant before the closing year. Third, instead of studying the yearly samples separately, we pooled the data for the 3 years. This enabled statistical testing of the effect of the year of displacement and the interaction of the year and the individual characteristics of the workers with the subsequent 7-year employment trajectory groups.

One strength of this study is its methodological credibility. The selection of differing business cycles was based on a diverse set of macroeconomic indicators, the pioneering application of modern statistics in the domain turned out to be useful, and the focus on a particular group of displaced workers provided a solid basis for the interpretation of future employment paths. The strict inclusion criteria are, on the other hand, a limitation, as the sample did not include individuals from the short-term and atypically contracted buffer workforce that lost jobs in the plant closures. Had our sample included at random citizens who were unemployed at a given point in time, the trajectory solution may have been similar, but the percentages of individuals entering the trajectories of strong employment would certainly have been smaller. For this reason, we would like to anchor the study to the context of plant closure research, and recommend caution in generalizing the findings. On the other hand, the results about 'case Finland' can be generalized internationally for plant closures in similar economic and institutional contexts. As for the background factors, we were limited to the contents of the FLEED database; certain important characteristics—such as indicators health and work ability, for instance-were not available.

We selected the years 1992, 1997, and 2003 as baseline time points of the followup. The choice of years was based on macroeconomic indicators like national GDP and the employment and unemployment rates. The selection worked well, and the findings verified that cyclical time matters and explains a lot of the variation in the employment patterns of displaced workers, and this is clear especially when comparing 1992 with 1997 and 2003. However, it is worth noting that the differences between 1997 and 2003 were less pronounced than we expected on the basis of the evident changes in the labor market preconditions suggested by the macroeconomic indicators.

\section{Conclusions}

This study is unique both with respect to the sample-employees who were strongly attached to the workplace before its closure-and with respect to the methods-trajectory analysis of the employment and subsequent regression analyses. Therefore, the results cannot be considered strictly in terms of verifying or falsifying the findings of earlier Finnish or international studies. Some comparisons are, however, possible. The exceptionality of our results for 1992 is consistent with Gartell et al. (2010) and Farber (2011), who studied the cyclical development of job reallocation, but-in terms of the integrative capacity, selectivity of demand, and development of employment trajectories in the long run-our findings bring important new light to the topic of the restructuring and adaptation of the labor market.

While testing our hypothesis with a regression analysis, the individual characteristics (age, gender, education) were considered to be confounding factors. The associations between year of displacement and trajectory remained practically unchanged when gender and education were added to the statistical model, whereas adding age to the model changed the RRR considerably. In order to test the sectoral shift hypothesis, 
we controlled the sector of industry and found that permanent changes in the industry structures and associated labor force demands do not explain the result.

In terms of policies and social outcomes, our results demonstrate the strong reintegrative capacity of the labor market, as threefourths of the sample was assigned to the trajectory group of continuously strong employment. Differences in labor market attachment between 1997 and 2003 were minor, which perhaps reflect the fact that new jobs were created and the demand for labor was relatively strong in 2003, despite the slow growth in the economy.

The Finnish and Nordic labor market policy emphasis is not so much on compensating for acquired benefits (the risk of income loss) but rather-and above all-on supporting workers who have experienced a mass lay-off in terms of re-employment and reintegration into the labor market. As to whether national flexicurity models can withstand global economic risks and whether it is altogether possible to protect the labor force from economic risks without international agreements and social dialogue, these remain open questions.

The principal analysis of our study gave credence to post-hoc analyses that suggest the institutions of the welfare state do contribute to employment trajectories, but this issue remains largely a subject for further research. The results of this study may also open up interesting perspectives for comparative research across the Nordic countries, which have similarities in terms of employment policy and the institutional settings of the welfare state.

\section{Acknowledgments}

The authors would like to thank the Finnish Work Environment Fund for their funding of this research.

\section{Appendix A}

Figure A I: The effect of age, controlling for gender and level of education, on the probability of falling onto the trajectory of recovering employment for workers displaced in 1992, 1997, and 2003.
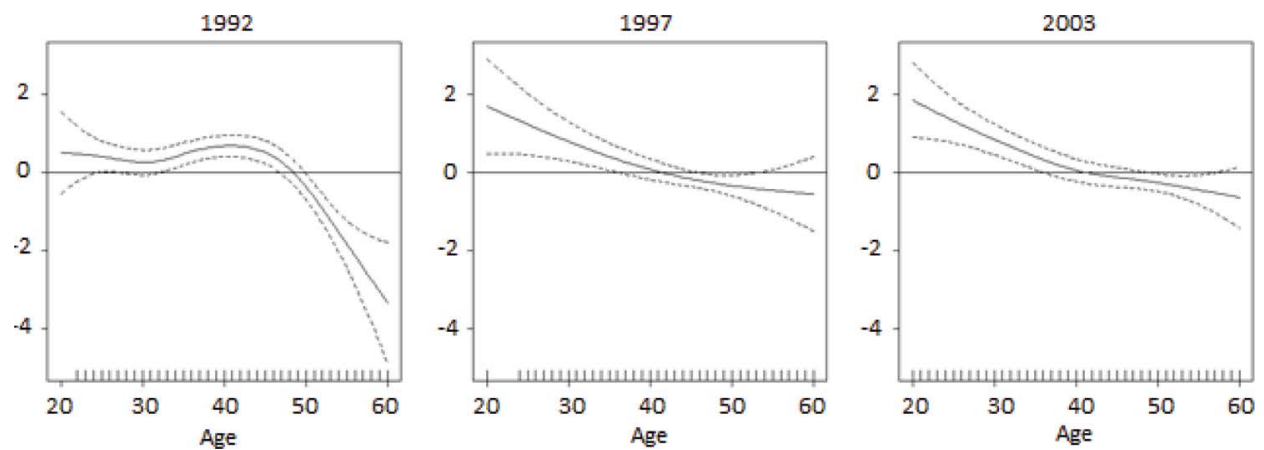

Note: Logit scale on the $y$-axis. The dashed lines show the $95 \%$ confidence interval. 
Figure A2: The effect of age, controlling for gender and level of education, on the probability of falling onto the trajectory of immediate exit from employment for workers displaced in 1992, 1997, and 2003.
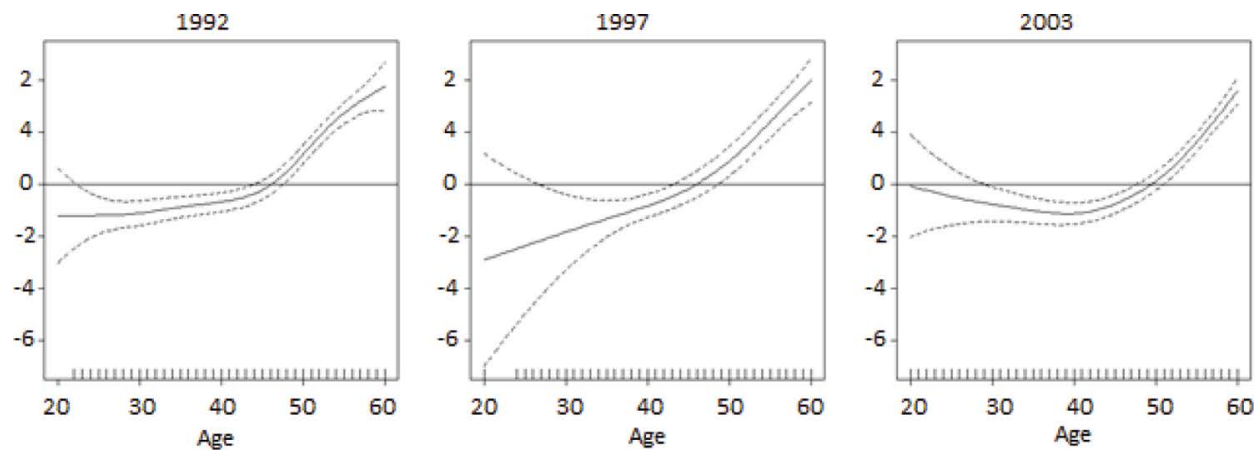

Note: Logit scale on the $y$-axis. The dashed lines show the $95 \%$ confidence interval.

\section{References}

Appelqvist, J. (2007). Wage and earnings loses of displaced workers in Finland. Discussion Papers 422, Helsinki: VATT Institute for Economic Research.

Asplund, R., Kauhanen, A. and Maliranta, M. (2012). Työtehtävien ja palkkojen dynamiikka (Dynamics of tasks and wages). Helsinki: Elinkeinoelämän tutkimuslaitos.

Becker, G. S. (1975). Human Capital: Theoretical and Empirical Analysis with Special Reference to Education, 2nd edition: Columbia University Press.

Barth P. S. (1971). Time series analysis of layoff rates. Journal of Human Resources 6, Fall, pp. 448-65.

Boockmann, B. and Steffes, S. (2007). Seniority and job stability: A quantile regression. Approach using matched employer-employee data. ZEW Discussion Paper no. 07-014, Mannheim: Centre for European Economic Research.

Chiarini B. and Piselli, P. (2000). Unemployment, Wage Pressure and Sectoral Shifts: Permanent and Temporary Consequences of Intersectoral Shocks. Journal of Policy Modeling 22 (7): 777-799.

Cutler D., Huang, W. and Lleras-Muney, A. (2014). When does education matter? The protective effect of education for cohorts graduating in bad times. Working Paper no. 20156, Cambridge, MA: National Bureau of Economic Research.

Dempster, A., Laird, N. and Rubin, D. (1977). Maximum likelihood estimation for incomplete data via the EM algorithm. Journal of the Royal Statistical Society 39: 1-38.

Eliason, M. and Storrie, D. (2009). Job loss is bad for your health - Swedish evidence on cause-specific hospitalization following involuntary job loss. Social Science \& Medicine 68: 1396-1406.

Farber, H. S. (2005). What do we know about job loss in the United States? Evidence from the displaced workers survey 1984-2004. Working Paper 498, Industrial Relations Section, Princeton University.

Farber, H. S. (2011). Job Loss in the great recession: Historical perspective from the displaced workers survey 1984-2010, Working Paper 564, Industrial Relations Section, Princeton University. 
Frederiksen, A. and Westergaard-Nielsen, N. (2007). Where did they go? Modelling transitions out of jobs. Labour Economics 14: 811-828.

Frederiksen, A. (2008). Gender differences in job separation rates and employment stability: New evidence from employer-employee data. Labour Economics 15: 915-937.

Gartell, M., Jans, A-C. and Persson, H. (2010). The importance of education for the reallocation of labor: Evidence from Swedish employer-employee data 1986-2002. Labour Economics 17: 206-214.

Hall, R. E., Farber, H. and Haltiwanger, J. (1995). Lost Jobs. Brookings Papers on Economic Activity 1995: 221-273. 25th Anniversary issue.

Houle, M. and Van Audenrode, M. (1995). Job displacement, wages and unemployment duration in Canada. Labour Economics 2: 77-91.

Huttunen, K., Møen, J. and Salvanes K. G. (2011). How Destructive is creative destruction? Effects of job loss on job mobility, withdrawal and income. Journal of the European Economic Association 9: 840-870.

Jolkkonen, A. and Kurvinen, A. (2009). Joustavuus ja turvallisuus irtisanomistilanteissa Tapaustutkimus Perlos Oyj:n tuotannon lopettamisesta Joensuu seudulla (Flexibility and security in a lay-off situation - A case study of the closing down of the Perlos Oyj LTD in the Joensuu region). Työ- ja elinkeinoministeriön julkaisuja. Työ ja yrittäjyys 72. Helsinki: Edita Publishing.

Jolkkonen, A., Koistinen, P. and Kurvinen, A. (2012). Reemployment of displaced workers The case of a plant closing on a remote region in Finland. Nordic Journal of Working Life Studies 2: 81-100.

Jolkkonen, A., Koistinen, P., Kurvinen, A., Lipiäinen, L., Nummi, T. and Virtanen, P, (2014). Kohtalokkaat olosuhteet ja yksilölliset tekijät: toimipaikan lakkauttamisen seurauksena työnsä menettäneiden kiinnittyminen työmarkkinoille. (Critical circumstances and individual factors: labor market attachment of displaced workers after job loss due to the plant closure). Kansantaloudellinen aikakauskirja 4: 492-515.

Jolkkonen, A., Koistinen, P., Kurvinen, A., Lipiäinen, L., Nummi, T. and Virtanen, P, (2017). Labour market attachment following major workforce downsizings: a comparison of displaced and retained workers. Work, employment and society (in press).

Jones, B. L., Nagin, D. S. and Roeder, K. (2001). A SAS procedure based on mixture models for estimating developmental trajectories. Sociological Methods \& Research 29: 374-393.

Jung, T., and Wickrama K. A. S. (2008). An introduction to latent class growth analysis and growth mixture modeling. Social and Personality Psychology Compass 2: 302-317.

Järnefelt, N. (2010). Education and Longer Working Lives. A longitudinal study on education differences in the late exit from working life of older employees in Finland. Finnish Centre for Pensions, Studies 2010: 1.

Kletzer, L. G. (1998). Job displacement. The Journal of Economic Perspectives 12: 115-136.

Klingvall, M. (1998). Företagens rekryteringsmetoder - hur arbetslösä får job. Arbetmarknad \& Arbetsliv 4: 291-303.

Koeber, C. and Wright, D. W. (2006). Gender differences in the reemployment status of displaced workers human capital as signal that mitigate effects of bias. The Journal of Socio-Economics 35 (2006): 780-796, doi: http://dx.doi.org/10.1016/j.socec.2005. 11.036.

Kollmeyer, C. and Pichler, F. (2013). Is Deindustrialization Causing High Unemployment in Affluent Countries? Evidence from 16 OECD Countries, 1970-2003. Social Forces (2013) 91 (3): 785-812. doi: http://dx.doi.org/10.1093/sf/sos184.

Korkeamäki, O. and Kyyrä, T. (2008). A distributional analysis of displacement costs in an economic depression and recovery. Discussion Papers 465, Helsinki: VATT Institute for Economic Research. 
Korkeamäki, O. and Kyyrä, T. (2014). A distributional analysis of earnings losses of displaced workers in an economic depression and recovery. Oxford Bulletin of Economics and Statistics 76: 565-588.

Kuhn, P. J. (2002). Summary and Synthesis.In Losing work, moving on: International perspectives on worker displacement, ed. Peter J. Kuhn. Kalamazoo: W. E. Upjohn Institute for Employment Research.

Kyyrä, T. (2015). Early retirement policy in the presence of competing exit pathways: Evidence from pension reforms in Finland.Economica 82: 46-78.

Lilien D. (1982). Sectoral shifts and cyclical unemployment.Journal of political economy 90: 4, 777-93.

Liu, K., Salvanes, K. G. and Sørensen, E. Ø. (2016). Good skills in bad times: Cyclical skill mismatch and the long-term effects of graduating in a recession.European Economic Review 84 (2016): 3-17. doi: http://dx.doi.org/10.1016/j.euroecorev.2015.08.015.

Nagin, D. S. (1999). Analyzing developmental trajectories: A semiparametric, group-based approach.Psychological Methods 4: 139-177.

Nagin, D. S. (2005). Group-based modeling of development. Cambridge: Harvard University Press.

Neffke F, Otto A. and Hidalgo C. (2016). The mobility of displaced workers: How the local industry mix affects job search strategies. Working papers No. 71. Center for International Development at Harvard University.

Nedelkoska, L., Neffke F. and Wiederhold S. (2015). Skill Mismatch and the Costs of Job Displacement. Retrieved from: https://www.aeaweb.org/conference/2015/retrieve.php?pdfid $=1264$

Ministry of Employment and the Economy, Annual Employment Service Statistics 1991-2013; Retrieved from: http://www.tem.fi/en/work/employment service statistics/statistical publications/statistical summary -annuals

Ormiston, R. (2014). Worker displacement and occupation-specific human capital. Work and Occupations, 41: 350-384. doi: http://dx.doi.org/10.1177/0730888414531500.

Statistics Finland, Annual national accounts 1991-2013. Retrieved from: http://www.stat.fil til/vtp/index en.html

Statistics Finland, Statistical Yearbook of Finland, 1990-2013. Retrieved from: http://www. stat.fi/tup/kirjasto tieto/tilastolliset vuosikirjat.html

Statistics Finland, StatFin database

Stevens, A. H. (1997). Persistent effects of job displacement: The importance of multiple job losses. Journal of Labor Economics 15: 165-188.

Verho, J. (2008). Scars of recession: the long-term costs of the Finnish economic crisis. Working paper 9. IFAU - institute for Labour Market Policy Evaluation, Uppsala.

Wood, S. N. (2006). Generalized Additive Models - An Introduction with R. Boca Raton: CRC Press.

\section{Notes}

${ }^{1}$ The content description of the combined Finnish Longitudinal Employer-Employee Data (FLEED) is available online at http://www.stat.fi/tup/mikroaineistot/me kuvaus henkilo en.pdf. 